\title{
PELATIHAN AKUNTANSI BIAYA DAN HPP PADA UMKM DESA WISATA PONGGOK KLATEN
}

\author{
Aryani Intan Endah Rahmawati ${ }^{*}$, Suyatmin Waskito Adi ${ }^{2}$ \\ ${ }^{1}$ Akuntansi Syariah, UIN Raden Mas Said Surakarta \\ ${ }^{2}$ Akuntansi, Universitas Muhammadiyah Surakarta \\ email: aryani.rahmawati@iain-surakarta.ac.id
}

\begin{abstract}
CoGS) for micro, small, and medium enterprises (MSMEs) in Ponggok Tourism Village was carried out to provide understanding and training in calculating CoGS. Based on the initial survey conducted by the community service team, information was obtained that seller in Ponggok Village did not calculate CoGS properly because they based their selling price on market prices. This is because MSMEs have a similar business, namely a culinary business. This unsuitable selling price determination will result in suboptimal profit achievement because each business has a different total cost. For this reason, this service carries out four training sessions to guide MSME players in deermining the appropriate selling price. The four sessions covered the delivery of concepts and materials, discussions, training in calculating CoGS, and evaluation. This community service is expected to increase understanding and skills in calculating CoGS so that optimal profit can be achieved.
\end{abstract}

Keywords: cost accounting; cost of good sold; ponggok village

\begin{abstract}
Abstrak: pelatihan akuntansi biaya dan penghitungan Harga Pokok Penjualan (HPP) pada pelaku UMKM di Desa Wisata Ponggok dilaksanakan untuk memberikan pemahaman dan pelatihan penghitungan HPP. Berdasarkan survei awal yang dilakukan tim pengabdian, didapatkan informasi bahwa para pelaku UMKM di Desa Ponggok tidak melakukan penghitungan HPP karena mendasarkan harga jualnya sesuai harga pasar. Hal ini dikarenakan para pelaku UMKM memiliki usaha yang sejenis, yaitu usaha kuliner. Penentuan harga jual yang tidak sesuai ini akan menyebabkan pencapaian laba yang tidak optimal karena setiap usaha memiliki berbagai total biaya yang berbeda. Metode yang digunakan dalam pengabdian masyarakat ini berbentuk pelatihan. Untuk itu, pengabdian ini melaksanakan empat sesi pelatihan untuk memandu para pelaku UMKM menentukan harga jual yang sesuai. Keempat sesi tersebut meliputi penyampaian konsep dan materi, diskusi, pelatihan penghitungan HPP, dan evaluasi. Pengabdian kepada masyarakat ini diharapkan dapat menambah pemahaman dan ketrampilan menghitung HPP sehingga laba yang optimal dapat tercapai.
\end{abstract}

Kata kunci: akuntansi biaya; harga pokok penjualan; desa ponggok 
Jurdimas (Jurnal Pengabdian Kepada Masyarakat) Royal

Vol. 5 No. 1, Januari 2022, hlm. 13 - 18

ISSN 2614-7912 (Print)

DOI: https://doi.org/10.33330/jurdimas.v5i1.1102

ISSN 2622-3813 (Online)

Available online at https:/jurnal.stmikroyal.ac.id/index.php/jurdimas

\section{PENDAHULUAN}

Usaha Mikro, Kecil, dan Menengah (UMKM) merupakan usaha produktif yang tengah berkembang pesat saat ini. Perkembangannya mendominasi usaha di Indonesia dengan jumlah 65 juta UMKM yang tersebar di seluruh pelosok negeri (Christy, 2021). Hal ini menghasilkan kontribusi terhadap total Produk Domestik Bruto Indonesia sebesar $60,3 \%$ dan penyerapan tenaga kerja sebanyak 97\% (BRI, 2020).

Terdapat masalah mendasar bagi pelaku UMKM di Indonesia, yaitu kemampuan akuntansi yang terbatas (Sarfiah, Atmaja \& Verawati, 2019; Widiatmoko, Indarti, Puspitasari \& Hadi, 2020). Terbatasnya kemampuan ini termasuk kurangnya melakukan penghitungan Harga Pokok Produksi (HPP) dengan benar. Hal ini seperti yang dialami oleh para pelaku UMKM di desa Wisata Ponggok, Klaten.

Pelaku UMKM di desa Ponggok adalah pemilik usaha kuliner yang bertempat di lokasi Umbul Ponggok. Mereka rata-rata menjual produk yang sejenis sehingga menentukan harga jual produk hanya berdasarkan harga pasar. Padahal, harga jual produk seharusnya didasarkan pada berbagai biaya yang telah dikeluarkan dan tentunya berbeda pada setiap penjual. Harga jual produk ditentukan berdasarkan penghitungan HPP yang telah dilakukan sebelumnya. Oleh karena itu, pemahaman dan ketrampilan penghitungan HPP bagi para pelaku UMKM mutlak diperlukan.

HPP merupakan biaya pokok yang diperlukan untuk menghasilkan suatu produk (Widiatmoko, Indarti, Puspitasari \& Hadi, 2020). Berbagai biaya ini termasuk biaya langsung dan biaya tidak langsung. Biaya langsung merupakan biaya utama penyebab suatu produk dihasilkan (Mulyadi, 2012). Biaya ini terdiri dari biaya bahan baku dan biaya tenaga kerja langsung. Sedangkan biaya tidak langsung adalah biaya yang tidak langsung memengaruhi produksi suatu produk. Biaya ini termasuk biaya overhead pabrik.

Total dalam berbagai biaya langsung dan tidak langsung ditambah keuntungan yang diinginkan akan menentukan harga jual produk. Penetapan HPP yang akurat akan menghasilkan harga jual yang sesuai. Harga jual yang sesuai mutlak diperlukan agar terjadi optimalisasi laba. Jika harga jual yang ditetapkan terlalu tinggi akan berakibat pada penurunan daya beli konsumen (Sutisna, Ghofar, Sunawarman, Muslimat, \& Rohendi, 2018). Sebaliknya, jika harga jual terlalu rendah akan menyebabkan kerugian oleh penjual.

HPP merupakan bagian dari akuntansi biaya yang menekankan pada penentuan dan pengendalian biaya (Dunia \& Abdullah, 2012). Akuntansi biaya untuk penentuan HPP juga akan menentukan nilai persediaan. Hal ini berhubungan dengan penyusunan laporan posisi keuangan dan laporan laba rugi yang sangat berguna untuk pihakpihak yang membutuhkan, khususnya jika para pelaku UMKM ingin mencari modal dari luar.

Penyusunan HPP yang akurat bisa mengatasi permasalahan yang umum dihadapi oleh para pelaku UMKM, yaitu kesulitan mencari modal (Widiatmoko et al., 2020). Data Kementrian Koperasi dan UKM tahun 2019 menyebutkan bahwa 88\% UMK tidak memperoleh atau mengajukan kredit (Ismail, 2021). Penyusunan HPP yang akurat akan menghasilkan laporan laba rugi yang baik. Hal tersebut akan menjadi dasar evaluasi kelayakan yang baik bagi pelaku UMKM ketika mengajukan 
Available online at https:/jurnal.stmikroyal.ac.id/index.php/jurdimas

permohonan pinjaman.

Pengabdian mengenai penyusunan HPP pada UMKM telah banyak dilakukan baik pada sektor UMKM maupun perusahaan. Pada bulan Maret 2021 dilaksanakan pelatihan penghitungan HPP dengan metode ceramah, simulasi, dan dis-kusi pada UMKM kabupaten Pati (Mulyani, Gunawan, \& Nurkamid, 2021). Pelatihan penghitungan HPP juga dilaksanakan pada perusahaan di Manado agar tercipta laba yang optimal karena perusahaan mampu mengendalikan pendapatan dan biaya (Lasena, 2013).

Pengabdian ini memberikan pemahaman mengenai pentingnya penghitungan HPP kepada para pelaku UMKM di desa Wisata Ponggok. Hal tersebut dimaksudkan agar mereka mampu menghasilkan laba yang optimal ditengah persaingan produk yang sejenis. Selain itu pengabdian ini juga memberikan pelatihan penghitungan HPP agar diperoleh gambaran cara penerapannya secara nyata.

\section{METODE}

Metode yang digunakan dalam pengabdian masyarakat ini berbentuk pelatihan. Pengabdian masyarakat ini memberikan penyuluhan mengenai konsep dan pentingnya penghitungan HPP disertai gambaran penghitungan. Selain itu, terdapat pelatihan singkat mengenai cara penghitungan HPP untuk memberikan gambaran nyata bagi para pelaku UMKM.

Pelatihan penghitungan HPP ini dilaksanakan untuk para pelaku UMKM di Desa Wisata Ponggok, Klaten. Pelatihan ini dilaksanakan pada tanggal 17 Maret 2021 dengan peserta sebanyak 50 orang. Terdapat dua tahapan dalam pengabdian ini yang meliputi survei pra pelaksanaan dan pelaksanaan pengabdian. Survei pra pelaksanaan dilakukan untuk mengetahui permasalahan nyata yang dihadapi para pelaku UMKM. Pelaksanaan pengabdian berupa pelatihan penyusunan HPP dalam satu hari dan dibagi dalam empat sesi.

Sesi pertama adalah penyampaian materi mengenai konsep akuntansi biaya dan penghitungan HPP oleh narasumber. Sesi kedua adalah diskusi antara narasumber dan peserta. Permasalahan akuntansi disampaikan oleh peserta kemudian dianalisis dan diberikan solusi oleh narasumber. Sesi ketiga adalah pelatihan penghitungan HPP untuk memberikan gambaran nyata kepada para peserta. Sesi terakhir meliputi evaluasi baik dari narasumber maupun peserta mengenai keberlangsungan acara dari awal hingga akhir.

\section{PEMBAHASAN}

Pengabdian kepada masyarakat mengenai pelatihan penghitungan HPP ini dilaksanakan sebagai solusi dari survei yang dilaksanakan sebelum acara. Survei tersebut mengindikasikan bahwa para pelaku UMKM di Desa Wisata Ponggok belum melakukan penghitungan HPP secara benar. Mereka menentukan harga jual berdasarkan harga pasar karena rata-rata pesaing mereka menjual produk yang sejenis. Jika harga jual didasarkan pada harga pasar, pencapaian laba tidak optimal karena harga jual yang digunakan tidak sesuai. Harga jual harus didasarkan pada penghitungan HPP terlebih dahulu karena melibatkan penghitungan beban yang berbeda antar penjual. 
Available online at https:/jurnal.stmikroyal.ac.id/index.php/jurdimas

Sesi pertama meliputi penyampaian materi mengenai konsep akuntansi biaya dan penghitungan HPP oleh narasumber (Gambar 1). Peserta diberikan materi mengenai pengelompokan biaya untuk membuat suatu produk yang meliputi biaya bahan baku, tenaga kerja langsung, dan overhead pabrik. Peserta juga diberikan materi mengenai pentingnya penghitungan HPP, akibat jika tidak melakukan penghitungan HPP, serta cara melakukan peng-hitungan HPP.

Sesi kedua berisi diskusi masalah antara peserta dan narasumber. Peserta mengungkapkan bahwa mereka tidak menghitung berbagai biaya yang kecil untuk dimasukkan ke harga jual. Misalnya peserta tidak mempertimbangkan biaya transportasi yang digunakan untuk distribusi pengantaran produk dari tempat produksi ke lokasi berjualan. Mereka mengabaikan biaya ini karena dekatnya jarak antar kedua lokasi tersebut. Narasumber kemudian memberikan penjelasan bahwa biaya apapun yang telah dikeluarkan untuk menghasilkan produk yang dijual wajib dimasukkan sebagai penentuan harga jual. Berbagai pertanyaan dan permasalahan yang diungkapkan oleh peserta didiskusikan dengan narasumber untuk mendapatkan solusi.

Sesi ketiga meliputi pelatihan singkat penghitungan HPP untuk memberikan gambaran nyata kepada para peserta. Peserta diminta untuk menyusun daftar biaya apa saja yang dikeluarkan untuk menghasilkan produk yang dijualnya. Kemudian peserta diminta untuk mengklasifikasikan biaya-biaya tersebut masuk ke biaya bahan baku, tenaga kerja langsung, ataupun biaya overhead. Peserta kemudian diminta untuk menjumlahkan seluruh biaya dan membaginya dengan total produk yang di- produksi. Hal ini akan menghasilkan harga pokok penjual setiap produk peserta. Peserta kemudian diminta untuk menambahkan presentase laba yang diinginkan. Harga jual akan didapatkan dari total HPP dan presentase keuntungan.

Sesi terakhir diisi dengan evaluasi keberlangsungan acara. Narasumber memeriksa dan memberikan umpan balik terhadap keakuratan hasil pengklasifikasian biaya, penghitungan HPP, dan penentuan harga jual oleh peserta. Kemudian narasumber juga merangkum materi dan solusi permasalahan yang telah disampaikan. Para peserta memberikan umpan balik berupa kritik dan saran mengenai materi maupun acara yang bisa digunakan sebagai bahan pengabdian kepada masyarakat selanjunya.

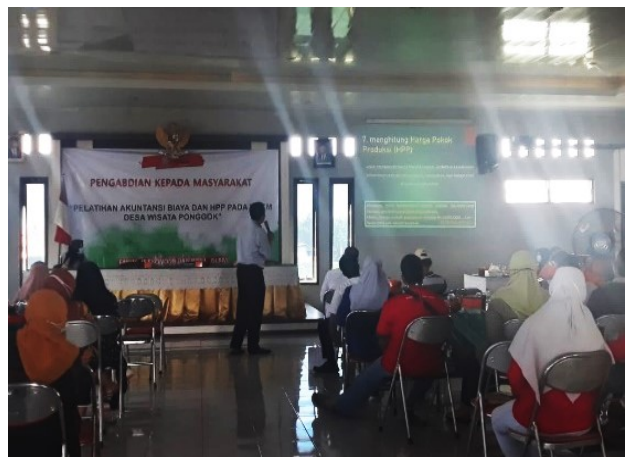

Gambar 1. Penyampaian Materi oleh Narasumber

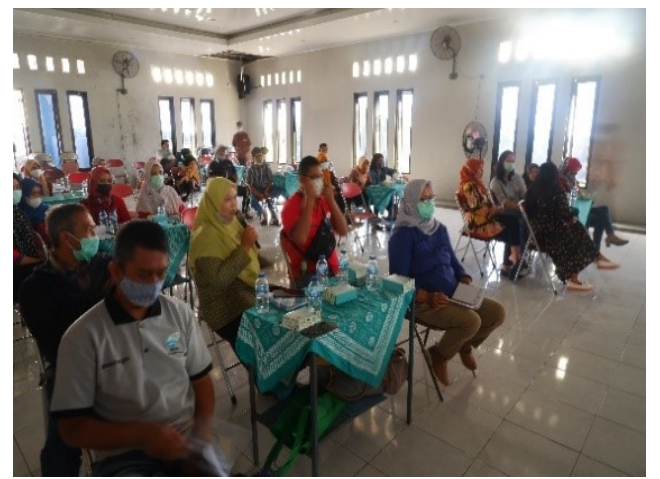

Gambar 2. Diskusi antara narasumber dan peserta 
Jurdimas (Jurnal Pengabdian Kepada Masyarakat) Royal

Vol. 5 No. 1, Januari 2022, hlm. 13 - 18

ISSN 2614-7912 (Print)

DOI: https://doi.org/10.33330/jurdimas.v5i1.1102

ISSN 2622-3813 (Online)

Available online at https:/jurnal.stmikroyal.ac.id/index.php/jurdimas

\section{SIMPULAN}

Pengabdian kepada masyarakat ini memberikan pemahaman dan pelatihan pada para pelaku UMKM di desa Wisata Ponggok. Pengabdian dilaksanakan dalam dua tahapan, yaitu survei awal dan pelaksanaan. Survei awal mengindikasikan kurangnya pemahaman peserta mengenai penghitungan HPP untuk menentukan harga jual. Pelaksanaan pengabdian berupa penyuluhan, diskusi, pelatihan penghitungan HPP, serta evaluasi. Berbagai rangkaian sesi yang telah berlangsung diharapkan dapat memberikan kontribusi dalam pemahaman dan ketrampilan penghitungan HPP pada para peserta sehingga menghasilkan harga jual yang sesuai.

\section{UCAPAN TERIMA KASIH}

Ucapan terima kasih disampaikan kepada FEBI IAIN Surakarta atas dukungan finansial terhadap pelaksanaan pengabdian masyarakat ini. Ucapan terima kasih yang sama kepada Kepala desa Ponggok, yang telah mendukung terlaksananya pengabdian kepada masyarakat ini dengan hadir pada saat acara. Serta para peserta pelaku UMKM di Desa Wisata Ponggok dan BUMDes Tirta Mandiri yang telah mengikuti pelatihan akuntansi biaya dan penghitungan HPP ini.

\section{DAFTAR PUSTAKA}

BRI. (2020, 26 Juni). Menyelamatkan UMKM, Menyelamatkan Ekonomi Indonesia [Halaman Web]. Diakses dari https://www.cnnindonesia.com/ ekonomi/20200626123545-297- 517786/menyelamatkan-umkmmenyelamatkan-ekonomiindonesia.

Christy, F.E. (2021, 23 Februari). Jumlah UMKM di Indonesia [Halaman Web]. Diakses dari https://data.tempo.co/data/1 111/jumlah-umkm-di-indonesia.

Dunia, F. A., \& Abdullah, W. (2012). Akuntansi biaya. Jakarta: Salemba Empat.

Giyanti, I., Suparti, E., Sunardi, S., \& Sugiarti, S. (2021). Perbaikan Proses Produksi dan Peningkatan Pemasaran pada UKM Putri Timus Di Karanganyar. Jurdimas (Jurnal Pengabdian Kepada Masyarakat) Royal, 4(2), 127134.

Ismail, T. (2021, 19 Februari). Bappenas: Besarnya Jumlah UMKM Belum Seimbang dengan Kontribusi pada PDB.

Lasena, S. R. (2013). Analisis Penentuan Harga Pokok Produksi pada PT. Dimembe nyiur agripro. Jurnal EMBA, 1(3), 585-592.

Mulyadi. 2012. Akuntansi Biaya. Yogyakarta: UPP STIM YKPN. Mulyani, S., Gunawan, B., \& Nurkamid, M. (2021). Pelatihan Perhitungan Harga Pokok Produksi Bagi Umkm Kabupaten Pati. Empowerment: Jurnal Pengabdian Masyarakat, 05(02), 529-534.

Sarfiah, S. N., Atmaja, H. E., \& Verawati, D. M. (2019). UMKM Sebagai Pilar Membangun Ekonomi Bangsa. Riset Ekonomi Pembangunan, 4(1), 119-127.

Sutisna, E., Ghofar, K. A., Sunawarman, A., Muslimat, M. K., \& Rohendi, A. (2018). 
Jurdimas (Jurnal Pengabdian Kepada Masyarakat) Royal Vol. 5 No. 1, Januari 2022, hlm. 13 - 18

Available online at https://jurnal.stmikroyal.ac.id/index.php/jurdimas

Pendampingan dalam

Perhitungan Harga Pokok

Produksi untuk Menentukan

Harga Jual Kue Kering Choco

Pink di JNC Cookies. Jurnal

Abdimas Bsi, 1(3), 446-453.

Widiatmoko, J., Indarti, M. G. K.,
Puspitasari, E., \& Hadi, S. S.

(2020). Pendampingan

Penyusunan Harga Pokok

Produksi Bagi Pelaku Umkm Di

Kota Semarang. 03(02), 206-

215. 